\title{
Purification and Properties of Nitrite Reductase from Escherichia coli K12
}

\author{
By KATHLEEN J. COLEMAN,* ATHEL CORNISH-BOWDEN and JEFFREY A. COLE \\ Department of Biochemistry, University of Birmingham, P.O. Box 363, Birmingham B15 2TT, U.K.
}

(Received 13 March 1978)

\begin{abstract}
NADH-nitrite oxidoreductase (EC 1.6.6.4) was purified to better than $95 \%$ homogeneity from batch cultures of Escherichia coli strain OR75Ch15, which is partially constitutive for nitrite reductase synthesis. Yields of purified enzyme were low, mainly because of a large loss of activity during chromatography on DEAE-cellulose. The quantitative separation of cytochrome $c-552$ from nitrite reductase activity resulted in an increase in the specific activity of the enzyme: this cytochrome is not therefore an integral part of nitrite reductase. The subunit molecular weights of nitrite reductase and of a haemoprotein contaminant, as determined by sodium dodecyl sulphate/polyacrylamide-gel electrophoresis, were 88000 and 80000 respectively. The sedimentation coefficient was calculated to be in the range 8.5-9.5 S, consistent with a mol.wt. of 190000. It is suggested therefore that the native enzyme is a dimer with two identical or similar-sized subunits. Purest samples contained $0.4 \mathrm{~mol}$ of flavin $/ \mathrm{mol}$ of enzyme, but no detectable haem. Catalytic activity was totally inhibited by $20 \mu \mathrm{M}$-p-chloromercuribenzoate and $1 \mathrm{mM}$-cyanide, slightly inhibited by $1 \mu \mathrm{M}$-sulphite and $10 \mathrm{~mm}$-arsenite, but was insensitive to $1 \mathrm{mM}-2,2^{\prime}$ bipyridine, $4 \mathrm{~mm}-1,10$-phenanthroline and $10 \mathrm{~mm}-\mathrm{NaN}_{3}$. Three molecules of $\mathrm{NADH}$ were oxidized for each $\mathrm{NO}_{2}{ }^{-}$ion reduced: the product of the reaction is therefore assumed to be $\mathrm{NH}_{4}{ }^{+}$. The specific activity of hydroxylamine reductase increased at each step in the purification of nitrite reductase, and the elution profiles for these two activities during chromatography on DEAE-Sephadex were coincident. It is likely that a single enzyme is responsible for both activities.
\end{abstract}

Some strains of Escherichia coli can grow anaerobically with nitrate or nitrite as sole nitrogen source (McNall \& Atkinson, 1956; Zarowny \& Sanwal, 1963; Fujita \& Sato, 1966; Cole et al., 1974). $\mathrm{NO}_{2}{ }^{-}$is assimilated during anaerobic growth on a fermentable carbon source, but is not assimilated during aerobic growth (Cole et al., 1974). The yields of bacteria from nitrogen-limited continuous cultures are the same whether $\mathrm{NO}_{2}{ }^{-}$or $\mathrm{NH}_{4}{ }^{+}$is supplied in the feed. Thus the nitrogen atoms of $\mathrm{NO}_{2}{ }^{-}$are assimilated and are not lost as gaseous denitrification side products.

Three different $\mathrm{NO}_{2}{ }^{-}$-reducing enzyme systems have been detected in cell-free extracts of $E$. coli (Lazzarini \& Atkinson, 1961; Zarowny \& Sanwal, 1963; Kemp \& Atkinson, 1966; Cole, 1968; Jones \& Garland, 1977). Two of these are unlikely to contribute substantially to $\mathrm{NO}_{2}{ }^{-}$reduction in vivo: one is a membrane-bound nitrite reductase that uses FMN or Benzyl Viologen as electron donor; the other is a soluble NADPH-dependent enzyme that functions in vivo primarily as a sulphite reductase. We shall be concerned in the present paper with the third,

* Present address: Biological Laboratory, University of Kent, Canterbury, Kent CT2 7NJ, U.K.
NADH-dependent nitrite reductase (NADH-nitrite oxidoreductase, EC 1.6.6.4), which accounts for the bulk of the $\mathrm{NO}_{2}{ }^{-}$-reducing capacity of strains that assimilate $\mathrm{NO}_{2}{ }^{-}$. There is a direct correlation between the presence or absence of this enzyme in strains $B_{n}$ or $B$ respectively, and their ability to assimilate $\mathrm{NO}_{3}{ }^{-}$or $\mathrm{NO}_{2}{ }^{-}$(Zarowny \& Sanwal, 1963; Kemp \& Atkinson, 1966). Highest activities have been found in high-speed supernatant extracts of bacteria from nitrogen-limited continuous cultures with either $\mathrm{NO}_{2}{ }^{-}$or $\mathrm{NH}_{4}{ }^{+}$as sole nitrogen source (Cole et al., 1974). Comparable activities have also been detected in anaerobic broth cultures of some chlorate-resistant mutants that are unable to reduce nitrate, but are partially constitutive for nitrite reductase and cytochrome $c$-552 synthesis (Venables et al., 1968; Newman \& Cole, 1977).

Full activity of the NADH-dependent nitrite reductase requires the presence of $\mathrm{NAD}^{+}$, a product of the reaction (Cornish-Bowden et al., 1973). Product activation of this kind is unusual, but not unprecedented: similar activation by $\mathrm{NAD}^{+}$has been reported for lipoamide dehydrogenase (Massey \& Veeger, 1961; Massey, 1963). Our primary aim was to purify and characterize the enzyme as a first step towards understanding the chemical basis and 
physiological role of product activation of $\mathrm{NO}_{2}^{-}$ reduction by $E$. coli.

Hyponitrite, hydroxylamine and nitrous oxide have all been postulated as intermediates in the reduction of $\mathrm{NO}_{2}^{-}$to $\mathrm{NH}_{4}{ }^{+}$, and all can be reduced by E. coli (McNall \& Atkinson, 1956; Payne, 1973). The purified sulphite reductase from $E$. coli will reduce hydroxylamine as well as $\mathrm{NO}_{2}{ }^{-}$and sulphite (Siegel et al., 1973), and preliminary evidence suggests that nitrite reductases from this and some other organisms are able to catalyse hydroxylamine reduction although sometimes only at very low rates (Kemp \& Atkinson, 1966; Zumft, 1972; Prakash \& Sadana, 1972; Ho \& Tamura, 1973; Lafferty \& Garrett, 1974; Hucklesby et al., 1976). In contrast, hydroxylamine reductases from Aspergillus nidulans, Pseudomonas aeruginosa and Azotobacter agile are separable from nitrite or sulphite reductases (Pateman et al., 1967; Spencer et al., 1957; Walker \& Nicholas, 1961). Our second aim was therefore to determine whether $\mathrm{NO}_{2}{ }^{-}$and hydroxylamine reduction by $E$. coli was catalysed by the same protein.

\section{Experimental}

\section{Bacteria}

E. coli K12 strain OR75 is a prototrophic Hfr (high frequency of recombination strain) that was isolated by Dr. R. Curtiss, III, Virginia Polytechnic Institute, Blacksburg, VA, U.S.A. Strain OR75Ch15 was isolated in this laboratory by Dr. B. M. Newman as a spontaneous mutant of strain OR75 that was resistant to $10 \mathrm{~mm}-\mathrm{KClO}_{3}$ during anaerobic growth (Newman \& Cole, 1977).

\section{Protein standards}

Alcohol dehydrogenase (EC 1.1.1.1; from yeast, crystalline; $440 \mu \mathrm{mol}$ of ethanol oxidized at $25^{\circ} \mathrm{C}$ and $\mathrm{pH} 8.8 / \mathrm{min}$ per $\mathrm{mg}$ ), catalase(EC1.11.1.6; bovine, $\mathrm{C} 100 ; 36000 \mu \mathrm{mol}$ of $\mathrm{H}_{2} \mathrm{O}_{2}$ decomposed at $25^{\circ} \mathrm{C}$ and $\mathrm{pH} 7.0 / \mathrm{min}$ per $\mathrm{mg}$ ), fumarate hydratase (EC 4.2.1.2; $330 \mu \mathrm{mol}$ of malate converted to fumate at $25^{\circ} \mathrm{C}$ and pH 7.6/min per mg), ovalbumin (grade V), phosphorylase $b$ (EC 2.4.1.1; from rabbit muscle) and transferrin (human) were obtained from Sigma (London) Chemical Co., Poole, Dorset BH17 7NH, U.K. Glutamate dehydrogenase (EC 1.4.1.2; $\mathrm{NH}_{3}$ free) was from Boehringer, Mannheim, W. Germany.

\section{Chemicals}

Coomassie Brillant Blue $R$ and Naphthalene Black 10B (Amido Black) were obtained from George T. Gurr Ltd., High Wycombe, Bucks., HP12 4HL, U.K. Casamino acids and nutrient broth were from Oxoid Ltd., Basingstoke RG24 6PW, U.K. Acrylamide, $N N^{\prime}$-methylenebisacrylamide and photoflow were from Eastman Chemicals, Liverpool L33 7UF, U.K. CNBr and $N N N^{\prime} N^{\prime}$-tetramethylethylenediamine were from Ralph N. Emmanuel, Wembley, Middx., U.K. Palladized asbestos $(5 \%$, $\mathbf{w} / \mathbf{w}$, palladium) and sodium arsenite were from Hopkin and Williams, Romford, Essex, U.K. DEAE-cellulose (DE-52) was from Whatman Biochemicals, Maidstone, Kent, U.K. Blue Dextran, Sephadex and Sepharose were from Pharmacia (G.B.) Ltd., London W5 5SS, U.K. Other chemicals were products of the highest available purity (except nucleotides, which were grade III) from Sigma, from BDH Chemicals, Poole, Dorset, BH12 4NN, U.K., or from Fisons Scientific Apparatus, Loughborough, Leics., U.K. 'White spot' (i.e. $\mathrm{O}_{2}$-free) $\mathrm{N}_{2}$ and $\mathrm{H}_{2}$ were obtained from British Oxygen Co., Wolverhampton WV1 2EP, U.K.

\section{Buffers}

Unless otherwise stated, $50 \mathrm{~mm}-\mathrm{Tris} / \mathrm{HCl}$ buffer, pH 8.0, containing $5 \mathrm{~mm}$-EDTA and $5 \mathrm{~mm}$-ascorbate (TEA buffer) was used for all experiments. This buffer was prepared at room temperature (about $25^{\circ} \mathrm{C}$ ) and was degassed before use.

\section{Methods}

Growth of bacteria and preparation of cell-free extracts. Continuous culture experiments were as described by Cole et al. (1974).

Nitrite reductase was isolated from strain OR75Ch15, which had been grown anaerobically in a 10-litre fermentation vessel at $37^{\circ} \mathrm{C}(\mathrm{L}$. H. Engineering Ltd., Stoke Poges, Bucks. SL24EG, U.K.). The culture medium contained $6.5 \mathrm{~g}$ of Oxoid nutrient broth/litre in nitrogen-free salts which were prepared as described by Cole $e$ al . (1974). Sterile 2.2M-glucose and, when specified, $20 \mathrm{mg}$ of L-cysteine hydrochloride $/ \mathrm{ml}$ were added aseptically to final concentrations of $44 \mathrm{~mm}$ and $2 \mathrm{mg} /$ litre respectively, after the bulk medium had been sterilized by autoclaving for $30 \mathrm{~min}$ at $117 \mathrm{kPa}\left(17 \mathrm{lb} / \mathrm{in}^{2}\right)$. Inocula that had been grown for $16 \mathrm{~h}$ in aerated nutrient broth at $37^{\circ} \mathrm{C}$ were transferred to 1.8 litres of culture medium in a 2-litre conical flask. After $10 \mathrm{~h}$ at $37^{\circ} \mathrm{C}$, this culture was used to inoculate 8 litres of medium in the fermentation vessel. The culture was maintained at pH7.2 \pm 0.1 by automatic addition of $5 \mathrm{M}-\mathrm{KOH}$. Cultures were stirred at $500 \mathrm{rev} . / \mathrm{min}$, but were not aerated. Bacteria were harvested at the end of the exponential phase of growth and were stored as described previously (Cole et al., 1974; Newman \& Cole, 1977).

Preparation of bacterial extracts. The bacterial pellet was thawed, mixed to a thin slurry with an equal volume of TEA buffer, and broken in a French pressure cell (French \& Milner, 1955) cooled to $4^{\circ} \mathrm{C}$ at a pressure of $60 \mathrm{MPa}\left(3.8 \mathrm{ton} / \mathrm{in}^{2}\right)$. After prelimi- 
nary centrifugation at $10000 \mathrm{~g}$ for $30 \mathrm{~min}$, the supernatant was decanted and further clarified by centrifugation at $75000 \mathrm{~g}$ for $2 \mathrm{~h}$ in an $8 \times 50 \mathrm{ml}$ rotor of an MSE 'Superspeed 50' centrifuge. To increase the yield by ensuring that most of the bacteria were broken, the pellet from the preliminary centrifugation was treated a second time as if it were a fresh bacterial pellet, and the supernatant obtained was combined with other supernatant fractions.

After cell breakage all procedures were carried out at $4^{\circ} \mathrm{C}$.

Measurement of the rate of NADH-dependent reduction of $\mathrm{NO}_{2}{ }^{-}$and hydroxylamine. For routine assays, $1.5 \mathrm{ml}$ or $4 \mathrm{ml}$ open cuvettes contained 1.0 or $3.0 \mathrm{ml}$ of $0.25 \mathrm{~mm}-\mathrm{NADH}, 1 \mathrm{~mm}-\mathrm{NAD}^{+}$and $2 \mathrm{~mm}-$ $\mathrm{NaNO}_{2}$ in TEA buffer at $30^{\circ} \mathrm{C}$. The reference cuvette contained $0.25 \mathrm{~mm}-\mathrm{NADH}$ in TEA buffer. The reaction was initiated by adding the enzyme sample. The rate of NADH oxidation in the absence of $\mathrm{NO}_{2}{ }^{-}$ was also measured and subtracted from the rate in the presence of $2 \mathrm{mM}-\mathrm{NO}_{2}{ }^{-}$to give the nitrite reductase activity.

A less expensive and less accurate assay was used to detect enzyme activity in fractions collected from chromatography columns. The rate of NADH oxidation in $2.3 \mathrm{ml}$ of TEA buffer containing $0.13 \mathrm{~mm}$ $\mathrm{NADH}$ and $0.65 \mathrm{~mm}-\mathrm{NAD}^{+}$was first determined. After $1 \mathrm{~min}, \mathrm{NaNO}_{2}$ was added to a final concentration of $2 \mathrm{mM}$, and the rate of NADH oxidation was again determined. The difference between the rates before and after the addition of $\mathrm{NaNO}_{2}$ was proportional to the nitrite reductase activity determined by the more rigorous method, but this method consistently gave lower activities because the enzyme was partially inactivated during the period before the nitrite was added, and because samples were assayed at $18-20^{\circ} \mathrm{C}$.

Hydroxylamine hydrochloride $(10 \mathrm{~mm})$ replaced $\mathrm{NO}_{2}{ }^{-}$when hydroxylamine reductase activities were determined.

A unit of hydroxylamine or nitrite reductase activity is defined as the amount of enzyme that catalyses the oxidation of $1 \mathrm{nmol}$ of NADH in $1 \mathrm{~min}$.

Protein. Protein concentrations were measured by the micro-tannin turbidimetric method of MejbaumKatzenellenbogen \& Drobryszycka (1959). The method was free from interference by EDTA, thiol reagents, ascorbate and Tris buffers, but high concentrations of $\mathrm{NAD}^{+}(6 \mathrm{~mm})$ did cause erroneous results. Turbidity was measured at $500 \mathrm{~nm}$ in a Unicam SP. 600 spectrophotometer. A standard curve was obtained with bovine serum albumin (10$100 \mu \mathrm{g} / \mathrm{ml}$ ) each day the method was used.

The protein eluted from chromatographic columns was monitored at $A_{\mathbf{2 8 0}}$, but only when ascorbate, which increases the background $A_{\mathbf{2 8 0}}$, was absent from the buffer system.

Nitrite. Nitrite was assayed colorimetrically by an adaptation of the method of Radcliffe \& Nicholas (1968). Samples containing $20-200 \mathrm{nmol}$ of $\mathrm{NO}_{2}{ }^{-}$ were diluted to $1 \mathrm{ml}$ with distilled water and mixed with $8.9 \mathrm{ml}$ of $1 \%(\mathrm{w} / \mathrm{v})$ sulphanilamide in $1 \mathrm{M}-\mathrm{HCl}$ and $1 \mathrm{ml}$ of $0.2 \%(\mathrm{w} / \mathrm{v}) \mathrm{N}$-(1-naphthyl)ethylenediamine dihydrochloride. After $20 \mathrm{~min}$ at room temperature $\left(18-20^{\circ} \mathrm{C}\right)$ the $A_{540}$, measured against a reagent blank, was proportional to the amount of $\mathrm{NO}_{2}{ }^{-}$in the sample.

Salts. Concentrations of $\mathrm{KCl}$ in fractions collected after column chromatography, or of $\left(\mathrm{NH}_{4}\right)_{2} \mathrm{SO}_{4}$ in fractions after gel filtration, were determined with a conductivity meter, type CDM (Radiometer, Copenhagen, Denmark).

Cytochromes. The concentration of cytochrome c-552 was measured by difference spectroscopy with either a Cary 14 or a Unicam SP. 1800 recording spectrophotometer, as described by Cole \& Ward (1973). Absorption spectra of the $b$-type cytochrome that co-purified with nitrite reductase were recorded with a Perkin-Elmer 356 double-beam spectrophotometer.

Extraction of haem. Haem was extracted by the method described by Murphy et al. (1973) for the extraction of the haem-like prosthetic group of sulphite reductase.

Flavin. Flavin in partially purified samples of enzyme was determined qualitatively by the method of Bessey et al. (1949); FAD and FMN in purified extracts were determined quantitatively as described by Faeder \& Siegel (1973).

Polyacrylamide-gel electrophoresis. Polyacrylamide gels with a final acrylamide concentration of 6 or $7 \%(\mathrm{w} / \mathrm{v})$ were cast either in glass columns $(9 \mathrm{~cm} \times$ $0.4 \mathrm{~cm}$ or $15 \mathrm{~cm} \times 0.4 \mathrm{~cm}$ diameter) as described by Davis (1964), or in a vertical glass slab apparatus $(21 \mathrm{~cm} \times 6 \mathrm{~cm} \times 0.3 \mathrm{~cm})$ by the method of Akroyd (1967) as modified by Perrie \& Perry (1970). For electrophoresis under dissociating conditions, $6 \%$ (w/v) polyacrylamide was polymerized with freshly prepared ammonium persulphate, and the buffer was $0.2 \%(\mathrm{w} / \mathrm{v})$ sodium dodecyl sulphate in $0.02 \mathrm{M}$ sodium phosphate, $\mathrm{pH}$ 7.0. Protein solutions were adjusted to $2 \mathrm{mg} / \mathrm{ml}$ and dialysed for $16 \mathrm{~h}$ against $4 \%$ (w/v) sodium dodecyl sulphate, $1 \%$ (w/v) 2-mercaptoethanol and $4 \mathrm{M}$-urea in $0.1 \mathrm{M}$-sodium phosphate, $\mathrm{pH}$ 7.0. Bromophenol Blue $[0.1 \mathrm{ml}$ of a $0.05 \%(\mathrm{w} / \mathrm{v})$ stock solution to $1 \mathrm{ml}$ of protein] was added, 10 $200 \mu \mathrm{l}$ samples were carefully layered on to the gel in each tube and a current of $7 \mathrm{~mA} /$ tube was applied. After $6-7 \mathrm{~h}$ at room temperature, gels were stained for $2-10 \mathrm{~h}$ with $0.25 \%(\mathrm{w} / \mathrm{v})$ Coomassie Brilliant Blue in $45.4 \%$ methanol and $9.2 \%$ acetic acid. Phosphorylase $b$ (mol.wt. 92000), transferrin (mol.wt. 77000), bovine serum albumin (mol.wt. 68000), catalase (mol.wt. 60000), glutamate dehydrogenase (mol.wt. 53000) and ovalbumin (mol.wt. 43000) were included in the gels as markers when appropriate. 
For electrophoresis under non-dissociating conditions, gels were photopolymerized with riboflavin and the gel buffer was $40 \mathrm{~mm}$-potassium phosphate, pH7.0. The electrophoresis buffer was $20 \mathrm{~mm}$ glycylglycine/ $\mathrm{NaOH}, \mathrm{pH} 8.0$, and 10-200 $\mu$ l samples contained $20 \%(\mathrm{w} / \mathrm{v})$ glycerol and Bromophenol Blue. A current of $5 \mathrm{~mA} /$ tube was applied for approx. 90 min, until the Bromophenol Blue had migrated to the bottom of the gel. This discontinuous system was unsuitable for attempts to detect bands of catalytically active enzyme after electrophoresis because it was impossible to pre-equilibrate the gels with $5 \mathrm{~mm}$-ascorbate and $5 \mathrm{~mm}$-EDTA. The gel system described by Davis (1964) was therefore modified as follows. Polyacrylamide gels $(7 \%)$ were prepared with $3.5 \mathrm{~g}$ of cyanogum $41,0.25 \mathrm{ml}$ of 3-dimethylaminopropionitrile, $4.2 \mathrm{ml}$ of $0.24 \mathrm{M}$-Tris $/ 1.19 \mathrm{M}$-glycine buffer, $\mathrm{pH} 8.3$, and water to $49.8 \mathrm{ml}$. The gels were polymerized in the dark with $0.2 \mathrm{ml}$ of $10 \%$ (w/v) ammonium persulphate. The electrophoresis buffer was $5 \mathrm{~mm}$-ascorbate and $5 \mathrm{~mm}$-EDTA in $20 \mathrm{~mm}$-Tris/126mm-glycine, $\mathrm{pH} 8.3$. The gels were pre-run for $2 \mathrm{~h}$ at $4^{\circ} \mathrm{C}$ to remove excess ammonium persulphate and to introduce the ascorbate, and active enzyme in $20 \%(\mathrm{w} / \mathrm{v})$ glycerol was loaded on to the surface. A current of $3 \mathrm{~mA} / \mathrm{gel}$ was then applied for $1.5 \mathrm{~h}$, until the Bromophenol Blue marker had run to the end of the gel.

Specific activity stain for nitrite reductase. Gels containing active nitrite reductase were incubated for $90 \mathrm{~min}$ at $30^{\circ} \mathrm{C}$ under $\mathrm{H}_{2}$ in a Thunberg tube that contained 2mM-NaNO${ }_{2}, 0.5$ mM-reduced Benzyl Viologen and approx. $0.1 \mathrm{mg}$ of palladized asbestos. The position of the enzyme was indicated by a colourless band with a width that increased with the amount of enzyme present and which contrasted with the blue colour of the rest of the gel. The bleaching is caused by the $\mathrm{NO}_{2}{ }^{-}$-dependent oxidation of reduced Benzyl Viologen, catalysed by nitrite reductase. Unfortunately this stain is soluble and autoxidizable. Gels stained with Benzyl Viologen were therefore transferred to a second Thunberg tube containing $2.5 \%(\mathrm{w} / \mathrm{v})$ triphenyltetrazolium chloride. The tube was then immediately evacuated. A paler region coincident with the original band of nitrite reductase activity was just visible against a red background, but the contrast was too slight for satisfactory photographs to be taken. Thus attempts to fix the stain and so preserve the electrophoretic pattern by using the reduced Benzyl Viologen to reduce a tetrazolium salt to a red insoluble formazan were only partially successful. These techniques were originally developed by Hucklesby \& Hageman (1973) to stain the ferredoxin-dependent nitrite reductase from plants.

Determination of the sedimentation coefficient of partially purified nitrite reductase. Linear $12.6 \mathrm{ml}$ gradients of $10-30 \%(\mathrm{v} / \mathrm{v})$ glycerol rather than sucrose were prepared as described by Martin \& Ames (1961). Preliminary experiments with 2,6dichlorophenol-indophenol in the more concentrated glycerol solution established that the gradients were linear for all fractions collected, except the first. Gradients were stored at $4^{\circ} \mathrm{C}$ for $4-18 \mathrm{~h}$ before use. Before each run, $0.3 \mathrm{ml}$ of sample in $5 \%(\mathrm{v} / \mathrm{v})$ glycerol was carefully layered on to each gradient. The polycarbonate tubes $(14 \mathrm{ml} ; 1.35 \mathrm{~cm}$ internal diameter $\times 9.5 \mathrm{~cm}$ length) were centrifuged at $196000 \mathrm{~g}_{\mathrm{av}}$. for $20 \mathrm{~h}$ at $1^{\circ} \mathrm{C}$ in a $6 \times 14 \mathrm{ml}$ swing-out rotor $\left(r_{\mathrm{av}}\right.$. $11.1 \mathrm{~cm}$ ) of an MSE 'Superspeed 65' centrifuge. After centrifugation, $210.6 \mathrm{ml}$ fractions from each gradient were collected through a thin-glass tube that had been carefully lowered through the gradient until it touched the bottom of the centrifuge tube.

Yeast alcohol dehydrogenase $\left(s_{20},{ }_{w}=7.4 \mathrm{~S}\right.$; mol.wt. 150000; Hayes \& Velick, 1954), fumarate hydratase $\left(s_{20, w}=9\right.$ S; mol.wt. 194000 ; Johnson \& Massey, 1957; Kanarek et al., 1964) and catalase $\left(s_{20, \mathrm{w}}=11.3 \mathrm{~S}\right.$; mol.wt. 250000 ; Sumner \& Gralen, 1938) were used as standards. After fractionation the activities of these standards were measured by the methods given in the Worthington manual (alcohol dehydrogenase) and the Sigma manual (fumarate hydratase and catalase). Nitrite reductase activities were also determined.

\section{Results}

\section{Determination of optimum growth conditions}

Previous studies have established that synthesis of nitrite reductase by $E$. coli is induced by nitrite, repressed by aeration and partially repressed during growth in media supplemented with amino acids and yeast extract (Cole, 1968; Cole et al., 1974). In preliminary experiments designed to optimize yields of the enzyme, bacteria were grown anaerobically in batch or continuous culture with $\mathrm{NO}_{2}{ }^{-}$as the only nitrogen source. Although moderately high specific activities were obtained, growth rates and cell yields were low and long exponential phases were observed before growth in batch culture commenced. In contrast, far higher yields of enzyme were obtained when the chlorate-resistant mutant strain OR75Ch15 was grown in batch culture in rich media unsupplemented with nitrite. Growth rates and cell yields were also far higher when this mutant was grown in nutrient broth than when the wild-type was grown with $\mathrm{NO}_{2}^{-}$as sole nitrogen source. The yield of nitrite reductase activity was further increased when L-cysteine hydrochloride was added to the culture. Although this was added to repress the synthesis of the NADPH-dependent sulphite reductase (Kemp et al., 1963), it is possible that this reducing agent increased the yield by protecting nitrite reductase from inactivation during harvesting procedures. 
Table 1. Purification of nitrite reductase activity from $E$. coli strain $O R 75 C h l 5$

Nitrite reductase activities were determined at $30^{\circ} \mathrm{C}$ with $1.0 \mathrm{~mm}-\mathrm{NAD}{ }^{+}$and $0.25 \mathrm{~mm}-\mathrm{NADH}$. All other experimental details are summarized in the text.

\begin{tabular}{|c|c|c|c|c|c|c|}
\hline Step & $\begin{array}{l}\text { Volume } \\
\text { (ml) }\end{array}$ & $\begin{array}{l}\text { Protein } \\
(\mathrm{mg} / \mathrm{ml})\end{array}$ & $\begin{array}{l}\text { Activity } \\
\text { (unit/ml) }\end{array}$ & $\begin{array}{l}\text { Yield } \\
(\%)\end{array}$ & $\begin{array}{c}\text { Specific activity } \\
\text { (units/mg of protein) }\end{array}$ & Purification \\
\hline 1. Crude extract & 225 & 25.0 & 13800 & 100 & 552 & 1 \\
\hline $\begin{array}{l}\text { 2. } 0-40 \%\left(\mathrm{NH}_{4}\right)_{2} \mathrm{SO}_{4} \\
\text { fractionation }\end{array}$ & 130 & 6.4 & 12300 & 51 & 1940 & 4 \\
\hline 3. DEAE-cellulose & 112 & 0.44 & 1160 & 4.3 & 2620 & 5 \\
\hline $\begin{array}{l}\text { 4. } 0-40 \%\left(\mathrm{NH}_{4}\right)_{2} \mathrm{SO}_{4} \\
\text { fractionation }\end{array}$ & 2.6 & 2.6 & 42600 & 3.5 & 16700 & 30 \\
\hline $\begin{array}{l}\text { 5. DEAE-Sephadex } \\
\text { peak fraction }\end{array}$ & 3.2 & & & & 5100 & \\
\hline
\end{tabular}

\section{Purification of nitrite reductase from cell-free extracts}

Nitrite reductase was usually purified from $100 \mathrm{~g}$ wet weight of $E$. coli strain OR75Ch15 which had been grown anaerobically in rich media either with or without additional L-cysteine hydrochloride. Solid $\left(\mathrm{NH}_{4}\right)_{2} \mathrm{SO}_{4}$ was slowly added to the high-speed supernatant extract until the solution was $40 \%$ saturated with the salt. After $1 \mathrm{~h}$ at $4^{\circ} \mathrm{C}$, precipitated protein was collected by centrifugation for $20 \mathrm{~min}$ at $34000 \mathrm{~g}$, redissolved in a minimum volume of TEA buffer and desalted on a column $(25 \mathrm{~cm} \times 4.0 \mathrm{~cm}$ diam.) of Sephadex G-25 gel. Fractions with nitrite reductase activity were pooled, loaded on to a column $(14.0 \mathrm{~cm} \times 2.8 \mathrm{~cm}$ diam.) of DEAE-cellulose DE-52 washed sequentially with $400 \mathrm{ml}$ of TEA buffer and $400 \mathrm{ml}$ of $0.1 \mathrm{M}-\mathrm{KCl}$ in TEA buffer, and eluted with an $800 \mathrm{ml}$ linear gradient of $0.1-0.3 \mathrm{M}-\mathrm{KCl}$ in TEA buffer. Fractions with nitrite reductase activity were pooled, precipitated with $40 \%$-satd. $\left(\mathrm{NH}_{4}\right)_{2} \mathrm{SO}_{4}$ and collected by centrifugation for $20 \mathrm{~min}$ at $34000 \mathrm{~g}$ and $4^{\circ} \mathrm{C}$. Sedimented proteins were dissolved in a minimum volume of TEA buffer, desalted by passage through a column $(20.5 \mathrm{~cm} \times 1.4 \mathrm{~cm}$ diam. $)$ of Sephadex G-25 equilibrated with TEA buffer and applied to a column $(15.5 \mathrm{~cm} \times 1.6 \mathrm{~cm}$ diam. $)$ of DEAE-Sephadex A-50. This column was washed with $150 \mathrm{ml}$ of $0.15 \mathrm{M}-\mathrm{KCl}$ in TEA buffer, and proteins were eluted with a $400 \mathrm{ml}$ linear gradient of 0.15 $0.4 \mathrm{M}-\mathrm{KCl}$ in TEA buffer. The nitrite reductase activity and protein concentration of individual and pooled fractions were determined at each stage of the purification: these results are summarized in Table 1 .

The poor final yield is mainly a consequence of a large loss of activity, accompanied by removal of most of the protein, during chromatography on DEAEcellulose DE-52 (step 3). Although it might seem that the degree of purification would be unaltered, but the yield improved, if this step were omitted, in practice the final $\left(\mathrm{NH}_{4}\right)_{2} \mathrm{SO}_{4}$ fractionation (step 4) was effective only when step 3 was included. The final purification of 30 -fold is apparently only a slight improvement on the 24 -fold purification reported by
Zarowny \& Sanwal (1963). However, the specific activity of their starting material was almost certainly much lower than ours, so it is likely that our final purity was correspondingly higher: direct comparisons are impossible, however, because assay conditions in the two studies differed greatly.

Step 5, fractionation on DEAE-Sephadex, was not used to prepare enzyme for kinetic studies, but it is included in Table 1 because active fractions after this procedure, unlike those from step 4 , migrated as an almost homogeneous band of protein during polyacrylamide-gel electrophoresis (Fig. 1). Faint bands of lower-molecular-weight contaminants contributed approx. $5 \%$ to the staining intensity of these gels. The specific activity frequently decreased during step 5 , however, so it is possible that this procedure separated two essential components of the enzyme. All attempts to obtain a preparation with a higher specific activity than 16.7 units/mg led to an unstable product with decreased specific activity.

Densitometric traces of the gels shown in Fig. 1 suggested that the most intense band in gel 4 (after step 4) accounted for about $22 \%$ of the stain and the less intense band at the same position as the single band in gel 5 contained about $13 \%$ of the stain.

\section{Separation of nitrite reductase activity from cytochrome} $c-552$

Cell-free extracts of bacteria with the highest nitrite reductase activity also contain a high concentration of cytochrome c-552 (Cole \& Wimpenny, 1968; Cole, 1968) and mutants defective in the nir $A$ gene lack both proteins (Cole \& Ward, 1973).

Consequently, it seemed possible that cytochrome c-552 was a component of nitrite reductase. However, gel filtration on Sephadex G-100 resulted in complete separation between nitrite reductase activity and cytochrome $c-552$ (Fig. 2). Enzyme activity was recovered in a yield of $37 \%$, with an increase in specific activity from 51 to 87 munits/mg. Re-addition of fractions containing cytochrome $c-552$ to those

Vol. 175 
containing nitrite reductase activity had no effect on the enzyme activity. The separation could also be achieved by use of $\left(\mathrm{NH}_{4}\right)_{2} \mathrm{SO}_{4}$ fractionation and chromatography of DEAE-cellulose. Thus cytochrome $c-552$ is not an integral part of nitrite reductase.

\section{Purification and spectra of haemoprotein associated with nitrite reductase}

Haem-containing fractions from two DEAESephadex columns were pooled $(100 \mathrm{ml})$ and dialysed for $16 \mathrm{~h}$ at $4^{\circ} \mathrm{C}$ against $5 \mathrm{~mm}$-EDTA in $50 \mathrm{~mm}$-Tris $/ \mathrm{HCl}$ buffer, $\mathrm{pH}$ 8.0. The dialysed protein solution was applied to a column $(10.5 \mathrm{~cm} \times 1.5 \mathrm{~cm}$ diam. $)$ of DEAE-Sephadex A50. The column was washed with $0.1 \mathrm{M}-\mathrm{KCl}$ in the same buffer, and then with a $380 \mathrm{ml}$ linear gradient of $0.1-0.3 \mathrm{M}-\mathrm{KCl}$ in the same buffer. The $A_{280}$ and $A_{410}$ of protein fractions eluted from the column were then determined. The fraction with the highest concentration of haem was also the fraction with the most protein. Samples of this fraction were subjected to electrophoresis in the presence and absence of sodium dodecyl sulphate, and in each case only one major band of protein was detected, which migrated at the same rate as the major band of protein in the second $\left(\mathrm{NH}_{4}\right)_{2} \mathrm{SO}_{4}$ fraction (step 4; track 4 in Fig. 1). The absorption spectrum of this fraction from 700 to $350 \mathrm{~nm}$ was also recorded. A single absorbance band was observed at $410 \mathrm{~nm}$. When the sample was reduced with a few grains of sodium dithionite, three absorbance maxima were seen at 560,519 and $430 \mathrm{~nm}$. The $\alpha$-band at $560 \mathrm{~nm}$ was bleached when $0.5 \mathrm{mg}$ of $\mathrm{NaNO}_{2}$ was added to the dithionite-reduced sample: the Soret band moved to $420 \mathrm{~nm}$ but the position of the $519 \mathrm{~nm}$ band was unchanged.

Partially purified cytochrome from the second

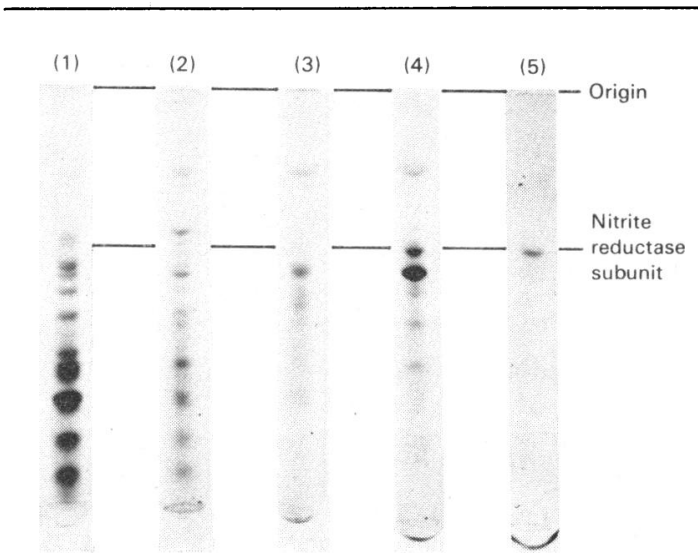

Fig. 1. Polyacrylamide-gel electrophoresis of nitrite reductase preparations

Gel conditions were $6 \%(\mathrm{w} / \mathrm{v})$ polyacrylamide, $0.1 \%$ $(\mathrm{w} / \mathrm{v})$ sodium dodecyl sulphate and $0.01 \mathrm{M}$-sodium phosphate, pH7.0. (1) High-speed supernatant extract; (2) proteins from the first $\left(\mathrm{NH}_{4}\right)_{2} \mathrm{SO}_{4}$ precipitate; (3) pool from DEAE-cellulose; (4) proteins from the second $\left(\mathrm{NH}_{4}\right)_{2} \mathrm{SO}_{4}$ precipitate; (5) nitrite reductase pool from the DEAE-Sephadex column. The numbers 1-5 correspond to purification steps 1-5 in Table 1.

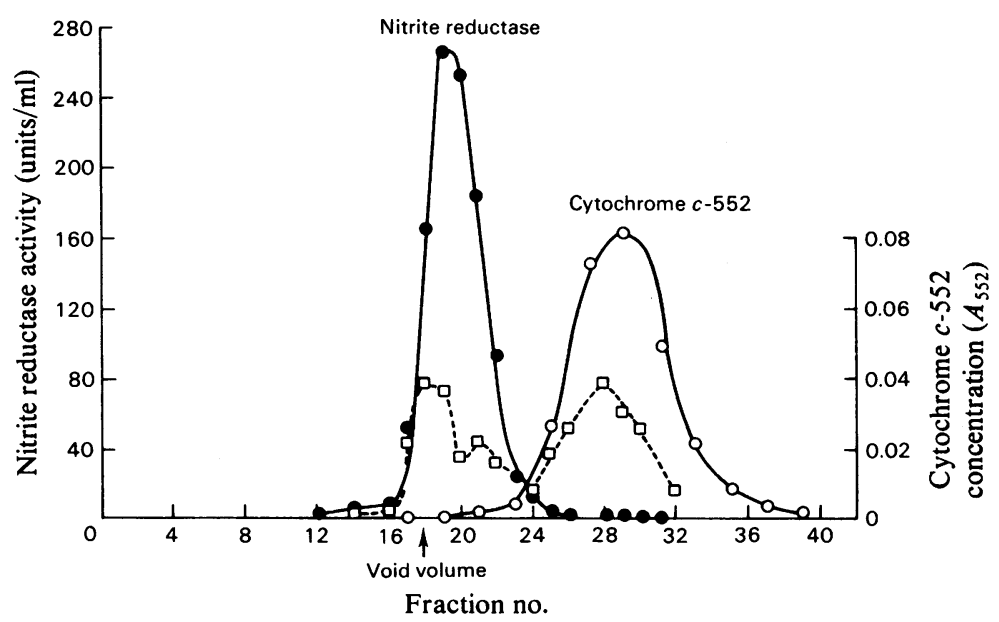

Fig. 2. Elution profiles of nitrite reductase activity and cytochrome c-552 from a Sephadex $G-100$ column High-speed supernatant extract $(3.0 \mathrm{ml} ; 36.0 \mathrm{mg}$ of protein $/ \mathrm{ml})$ was applied to and eluted from a column $(29.0 \mathrm{~cm} \times$ $2.5 \mathrm{~cm}$ diam.) of Sephadex G-100 in TEA buffer. The flow rate was $8.0 \mathrm{ml} / \mathrm{h}$, and $2.6 \mathrm{ml}$ fractions were collected. $\bullet$, Nitrite reductase activity assayed at $18-22^{\circ} \mathrm{C}$ with $0.13 \mathrm{~mm}-\mathrm{NADH}$ and $0.65 \mathrm{~mm}-\mathrm{NAD}^{+}$; $\square$, NADH oxidase activity assayed as above; $O$, cytochrome $c-552$. 
$\left(\mathrm{NH}_{4}\right)_{2} \mathrm{SO}_{4}$ fractionation of the enzyme purification was used to obtain a pyridine haemochromogen spectrum, which showed absorption maxima at 419 , 525 and $555 \mathrm{~nm}$. The similarity to the spectrum of protoporphyrin-IX, the prosthetic group of cytochrome $b$ (Falk, 1964), suggests that a $b$-type cytochrome is a major contaminant of partially purified nitrite reductase.

\section{Determination of the subunit molecular weight of nitrite reductase}

The molecular weights of nitrite reductase and the haemoprotein contaminant were estimated by comparison with standards after electrophoresis on polyacrylamide gels in the presence of sodium dodecyl sulphate. The mobilities of the various proteins were compared with that of the dye and were corrected for unequal gel shrinking as described by Weber \& Osborn (1969). The subunit mol.wt. of the nitrite reductase was $88000 \pm 540$ (S.E.M., 12 determinations) and the mol.wt. of the haemoprotein was $80000 \pm$ 1100 (s.E.M., eight determinations). The standard errors reflect the reproducibility of the experiments and do not allow for any systematic inaccuracies in the method: evidence from other proteins suggests that the method is accurate to within $10 \%$ (Weber \& Osborn, 1969).

\section{Estimation of the molecular weight of the native enzyme}

Partially purified nitrite reductase from step 4 was mixed with either fumarate hydratase or catalase and alcohol dehydrogenase and centrifuged on glycerol density gradients. The sedimentation coefficient of nitrite reductase, calculated by the method of Martin \& Ames (1961), was 8.5S with catalase as the standard, 9.0S with fumarase as the standard, and 9.5S with alcohol dehydrogenase as the standard (Fig. 3). These results are consistent with a mol.wt. of about 190000 , about double the value of 88000 found under dissociating conditions by sodium dodecyl sulphate/ polyacrylamide-gel electrophoresis. Nitrite reductase activity sedimented as an asymmetric peak: this suggests that it was partially aggregated. The rate of sedimentation was unchanged by the addition of $1 \mathrm{mM}-\mathrm{NAD}^{+}$before centrifugation. This concentration of $\mathrm{NAD}^{+}$is sufficient to promote substantial changes in the kinetic properties of the enzyme (Cornish-Bowden et al., 1973; Coleman et al., 1978).

\section{Attempts to characterize the catalytic centre}

Various metal-chelating agents were tested for their effect on the activity of nitrite reductase. EDTA stimulated activity (Ward, 1973), but other compounds such as $1 \mathrm{~mm}-2,2^{\prime}$-bipyridine, $4 \mathrm{~mm}-1,10$ phenanthroline and $10 \mathrm{~mm}-\mathrm{NaN}_{3}$ did not alter the rate of NADH oxidation. These observations suggest that nitrite reductase does not contain an accessible $\mathrm{Zn}$ or $\mathrm{Fe}$ atom as prosthetic group.

Despite the report by Kemp \& Atkinson (1966) that nitrite reductase activity was completely inhibited by 2 mM-sulphite, we observed only a $22 \%$ decrease in activity with $1 \mathrm{~mm}$-sulphite and a $24 \%$ decrease with $10 \mathrm{~mm}$-arsenite. In contrast, no activity could be detected in the presence of $1 \mathrm{~mm}-\mathrm{KCN}$. This might be interpreted as evidence for the presence of an essential metal atom or even a haem group, with cyanide being a competitive inhibitor of nitrite reductase (see, e.g. Vega et al., 1973): alternatively, the loss of activity might be due to the conversion of an essential carbonyl group into a cyanhydrin, but we have no direct evidence for these possibilities. The absence of an essential haem group was indicated by spectroscopic evidence. No absorbance maximum was detected in the range $380-600 \mathrm{~nm}$ in the spectrum of purified enzyme that was free of contamination by the $b$-type cytochrome, at a concentration of $0.63 \mathrm{mg}$ of protein $/ \mathrm{ml}$ and approximately $95 \%$ pure. If each 90000-dalton subunit contained a single haem group with an extinction coefficient of $20 \mathrm{~mm}^{-1} \cdot \mathrm{cm}^{-1}$, the absorbance of 0.13 unit would readily have been detected.

No activity could be detected when the enzyme was assayed in the presence of $20 \mu \mathrm{M}$-p-chloromercuribenzoate, but this inhibition was partially prevented by the presence of $10 \mathrm{~mm}$-cysteine. Zarowny \& Sanwal (1963) reported similar observations.

The method of Faeder \& Siegel (1973) was used to determine the amounts of FAD and FMN in purified extracts of nitrite reductase. An enzyme sample containing $0.08 \mathrm{mg}$ of protein $/ \mathrm{ml}$ contained $13 \mathrm{nM}$ FMN and $83 \mathrm{nM}-\mathrm{FAD}$. A sample of the same preparation of enzyme was subjected to sodium dodecyl sulphate/polyacrylamide-gel electrophoresis and a densitometric trace showed that the protein with subunit mol.wt. 88000 (i.e. nitrite reductase) accounted for about $50 \%$ of the protein and was contaminated with a protein band of higher molecular weight. Assuming therefore that the effective concentration of nitrite reductase was $0.04 \mathrm{mg}$ of protein $/ \mathrm{ml}$, and that its mol.wt. was 200000 , the flavin content was $0.07 \mathrm{~mol}$ of $F M N / \mathrm{mol}$ of enzyme and $0.4 \mathrm{~mol}$ of $\mathrm{FAD} / \mathrm{mol}$ of enzyme. This experiment does not, of course, establish whether nitrite reductase contains or requires any flavin because the amounts detected could have been associated with contaminating proteins rather than with the enzyme. Extraction of flavin from crude enzyme by the less drastic procedure of Kalse \& Veeger (1968) resulted in inactive enzyme that was not reactivated by the addition of $10 \mu \mathrm{M}-$ FAD. 

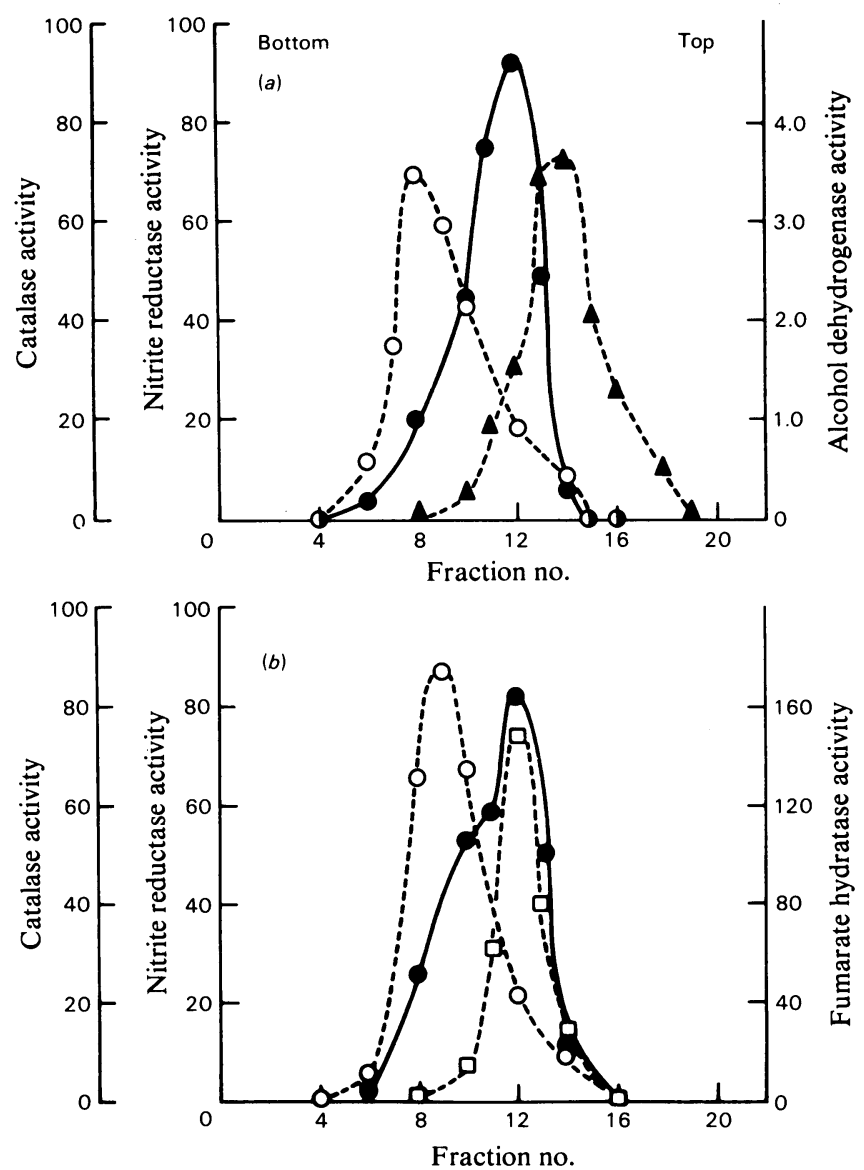

Fig. 3. Determination of the sedimentation coefficient of partially purified nitrite reductase by glycerol-density gradient centrifugation

Samples $(0.3 \mathrm{ml})$ containing $0.5 \mathrm{mg}$ of yeast alcohol dehydrogenase, $0.05 \mathrm{mg}$ of fumarate hydratase, $0.25 \mathrm{mg}$ of catalase and $0.63 \mathrm{mg}$ of protein from step 4 in the nitrite reductase purification scheme were layered on to the top of $12.6 \mathrm{ml}$ linear gradients of $10-30 \%(\mathrm{w} / \mathrm{v})$ glycerol in TEA buffer. The gradients were centrifuged at $196000 \mathrm{~g}_{\mathrm{av}}$. for $20 \mathrm{~h}$ at $1{ }^{\circ} \mathrm{C}$ in a $6 \times 14 \mathrm{ml}$ swing-out rotor $\left(r_{\mathrm{av}}, 11.1 \mathrm{~cm}\right)$ of an MSE 'Superspeed 65' centrifuge. After centrifugation, the gradients were fractionated $(21 \times 0.6 \mathrm{ml}$ fractions $)$ and the various enzyme activities were located. $\bigcirc$, Catalase activity $(\mu$ mol of $\mathrm{H}_{2} \mathrm{O}_{2}$ consumed $/ \mathrm{min}$ per $0.1 \mathrm{ml}$ of sample); $\Delta$, yeast alcohol dehydrogenase $\left(\mu \mathrm{mol}\right.$ of $\mathrm{NAD}^{+} \mathrm{reduced} / \mathrm{min}$ per $0.1 \mathrm{ml}$ of sample); $\square$, fumarate hydratase (nrinol of malate converted/min per $0.1 \mathrm{ml}$ of sample); $\bullet$, nitrite reductase activity assayed with $0.25 \mathrm{~mm}-\mathrm{NADH}$ and $1.0 \mathrm{~mm}^{-\mathrm{NAD}}{ }^{+}$at $30^{\circ} \mathrm{C}$ (units $/ 0.1 \mathrm{ml}$ of sample).

Table 2. Activity of hydroxylamine reductase at each stage in the purification of nitrite reductase Nitrite and hydroxylamine reductase activities were determined at $30^{\circ} \mathrm{C}$ with $0.25 \mathrm{~mm}-\mathrm{NADH}$ and $1.0 \mathrm{~mm}-\mathrm{NAD}^{+}$.

\section{Step}

1. High-speed supernatant extract

2. First $\left(\mathrm{NH}_{4}\right)_{2} \mathrm{SO}_{4}$ precipitate

3. DEAE-cellulose eluate

4. Second $\left(\mathrm{NH}_{4}\right)_{2} \mathrm{SO}_{4}$ precipitate

5. DEAE-Sephadex eluate
Nitrite reductase activity (units/ml)

15200

22200

1100

14600

606
Hydroxylamine reductase activity (units/ml)

18300

25300

1910

31900

1490
Ratio of rates with

$\mathrm{NO}_{2}{ }^{-}$and

hydroxylamine

$1: 1.2$

$1: 1.2$

$1: 1.7$

$1: 2.2$

$1: 2.5$ 


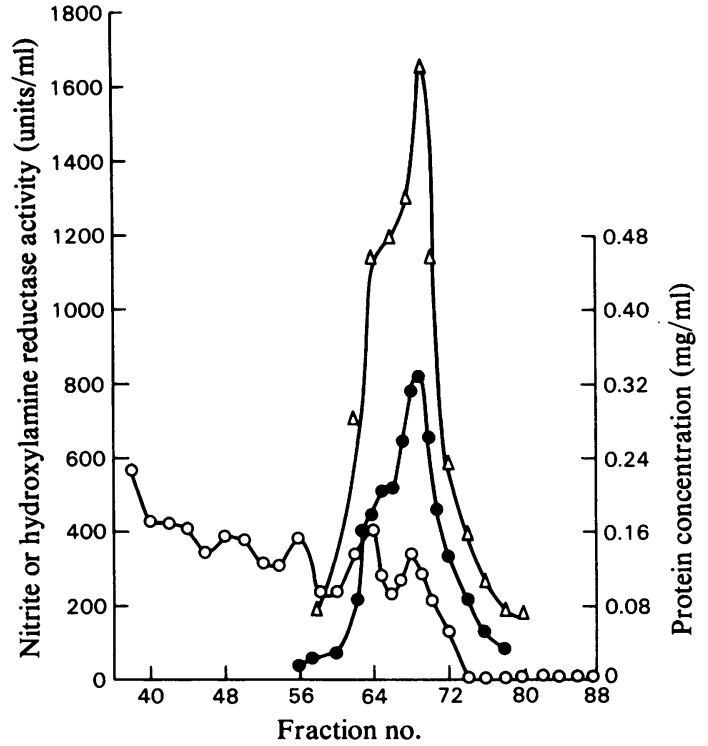

Fig. 4. Elution profile of nitrite reductase and hydroxylamine reductase activities from a DEAE-Sephadex A50 column

Nitrite reductase activity from the second $\left(\mathrm{NH}_{4}\right)_{2} \mathrm{SO}_{4}$ precipitation (step 4) was desalted and applied at $26 \mathrm{ml} / \mathrm{h}$ to a column of DEAE-Sephadex A50. Unbound protein was removed by washing the column with $150 \mathrm{ml}$ of TEA buffer containing $0.15 \mathrm{M}$ $\mathrm{KCl}$. A $380 \mathrm{ml}$ gradient of $0.15-0.40 \mathrm{M}-\mathrm{KCl}$ in TEA buffer was used to elute nitrite and hydroxylamine reductase activities: only part of the elution profile is shown. $\bullet$, Nitrite reductase activity assayed at $18-22^{\circ} \mathrm{C}$ with $0.13 \mathrm{~mm}-\mathrm{NADH}$ and $0.65 \mathrm{~mm}-\mathrm{NAD}^{+}$(units $/ \mathrm{ml}$ ); $\Delta$, hydroxylamine reductase activity (units $/ \mathrm{ml}$ ); $\mathrm{O}$, protein concentration determined by the microtannin method.

\section{Purification of hydroxylamine reductase}

The specific activity of hydroxylamine reductase increased throughout the initial steps in the purification of nitrite reductase, and the ratio of hydroxylamine to nitrite reductase activities increased rather than decreased (Table 2). The elution profiles for these two activities during chromatography on DEAE-Sephadex, the final step in the purification of nitrite reductase, were coincident, but the reaction velocity with $10 \mathrm{~mm}$-hydroxylamine as the substrate was 1.5 times that with $2 \mathrm{~mm}-\mathrm{NaNO}_{2}$ (Fig. 4). These observations confirm that nitrite reductase and hydroxylamine reductase activities are associated with a single enzyme complex.

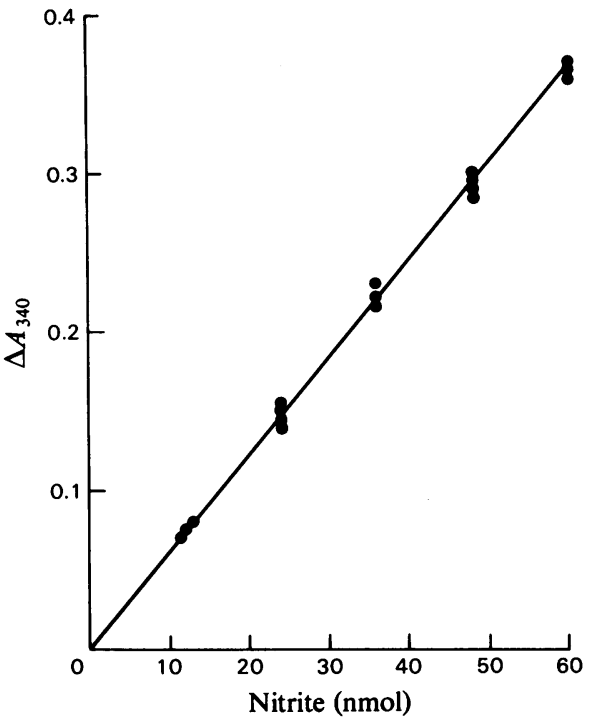

Fig. 5. Stoicheiometry of the reaction catalysed by nitrite reductase

Assay mixtures contained $3 \mathrm{ml}$ of $0.2 \mathrm{~mm}-\mathrm{NADH}$, $1 \mathrm{~mm}-\mathrm{NAD}^{+}, 200 \mu \mathrm{l}$ of partially purified nitrite reductase from step 4 (Table 2) and $0,12,24,36,48$ or $60 \mathrm{nmol}$ of nitrite in TEA buffer. The change in $A_{340}$ on addition of the enzyme in the absence of nitrite was subtracted from the change observed with nitrite, and the difference was plotted against the amount of nitrite added. Each determination was repeated three times: where data points overlap, they have been displaced slightly along the graph. From the slope of the graph (6.1 absorbance units $/ \mu \mathrm{mol}$ of nitrite) it can be calculated that $3.0 \mathrm{~mol}$ of NADH were oxidized for each mol of nitrite reduced.

\section{Stoicheiometry of the nitrite reductase reaction}

Three molecules of NADH were oxidized for each $\mathrm{NO}_{2}{ }^{-}$reduced (Fig. 5). The product of the reaction is therefore assumed to be $\mathrm{NH}_{4}{ }^{+}$.

\section{Discussion}

The conversion of nitrite into ammonia is a sixelectron reduction and one would hardly expect the enzyme-catalysed reaction to proceed in a single step. Nonetheless, we have been unable to find any clear evidence either for partially reduced intermediates or for a prosthetic group on the enzyme that could act as an electron carrier. The absence of detected intermediates may perhaps be explained on thermodynamic grounds by the fact that all of the intermediate 
oxidation states of nitrogen, nitric oxide, nitrous oxide, hydroxylamine, azide, di-imine and hydrazine, apart from the element itself, are unstable with respect to disproportionation to nitrite and ammonia. So, although there is no necessary relationship between thermodynamic stability and rate of reaction, it is certainly plausible that no intermediates are detected because the first step in the reaction is rate limiting. Indirect evidence that hydroxylamine might be an intermediate is provided by the fact that nitrite reductase catalyses the reduction of hydroxylamine by NADH.

Failure to detect a prosthetic group is more puzzling. Initially we thought that the contaminating cytochrome $c$-552 might be an essential component of the nitrite reductase. Both genetic studies (Newman \& Cole, 1977) and the initial difficulty in separating the enzyme activity from the cytochrome c-552 absorption suggested this, but it was excluded by the finding that complete separation could be achieved on Sephadex G-100, and that re-addition of cytochrome $c-552$ to the enzyme had no effect on its activity. Similarly, the $b$-type cytochrome that contaminates partially purified nitrite reductase appears to be irrelevant to its activity. Apart from cyanide, haemspecific reagents such as sulphite and arsenite have little effect on the enzyme and this, taken with the absence of a characteristic haem spectrum for the purified enzyme, makes it difficult to believe that a haem group is required for activity. The detection of $0.4 \mathrm{~mol}$ of $\mathrm{FAD} / \mathrm{mol}$ of enzyme in a preparation estimated to be $50 \%$ pure could be taken to indicate an FAD requirement for catalytic activity, but there is no certainty that this FAD is associated with the enzyme rather than with the impurities. The chemical characterization of the active site of nitrite reductase is thus in a rather unsatisfactory state and further experiments need to be done to improve it.

We are grateful to Miss Barbara Pirog for technical assistance during the initial phase of the project. K. J. C. was supported by a Research Studentship from the Science Research Council.

\section{References}

Akroyd, P. (1967) Anal. Biochem. 19, 399-410

Bessey, O. A., Lowry, O. H. \& Love, R. H. (1949) J. Biol. Chem. 180, 755-769

Cole, J. A. (1968) Biochim. Biophys. Acta 162, 356-368

Cole, J. A. \& Ward, F. B. (1973) J. Gen. Microbiol. 76, 21-29

Cole, J. A. \& Wimpenny, J. W. T. (1968) Biochim. Biophys. Acta 162, 39-48

Cole, J. A., Coleman, K. J., Compton, B. E., Kavangh, B. M. \& Keevil, C. W. (1974) J. Gen. Microbiol. 85, $11-22$
Coleman, K. J., Cornish-Bowden, A. \& Cole, J. A. (1978) Biochem. J. 175, 495-499

Cornish-Bowden, A., Ward, F. B. \& Cole, J. A. (1973) J. Gen. Microbiol. 75, xi

Davis, B. J. (1964) Ann. N. Y. Acad. Sci. 121, 404-429

Faeder, G. J. \& Siegel, L. M. (1973) Anal. Biochem. 53, 332-336

Falk, J. E. (1964) Porphyrins and Metalloproteins, Elsevier Scientific Publishing Co., Amsterdam

French, C. S. \& Milner, H. W. (1955) Methods Enzymol. 1, 64-67

Fujita, T. \& Sato, R. (1966) J. Biochem. (Tokyo) 60, 691-700

Hayes, J. E. \& Velick, S. F. (1954) J. Biol. Chem. 207, 225-244

Ho, C. \& Tamura, G. (1973) Agric. Biol. Chem. 37, 37-44

Hucklesby, D. P. \& Hageman, R. H. (1973) Anal. Biochem. 56, 591-592

Hucklesby, D. P., James, D. M., Banwell, M. J. \& Hewitt, E. J. (1976) Phytochemistry 15, 599-603

Johnson, P. \& Massey, V. (1957) Biochim. Biophys. Acta 23, 544-550

Jones, R. W. \& Garland, P. B. (1977) Biochem. J. 164, 199-211

Kalse, J. E. \& Veeger, C. (1968) Biochim. Biophys. Acta 159, 244-256

Kanarek, L., Marler, E., Bradshaw, F. A., Fellows, R. E. \& Hill, R. L. (1964) J. Biol. Chem. 239, 4207-4211

Kemp, J. D. \& Atkinson, D. E. (1966) J. Bacteriol. 92, 628-634

Kemp, J. D., Atkinson, D. E., Ehret, A. \& Lazzarini, R. A. (1963) J. Biol. Chem. 238, 3466-3471

Lafferty, M. A. \& Garrett, R. H. (1974) J. Biol. Chem. 249, 7555-7567

Lazzarini, R. A. \& Atkinson, D. E. (1961) J. Biol. Chem. 236, 3330-3335

Martin, R. G. A. \& Ames, B. N. (1961) J. Biol. Chem. 236, 1372-1379

Massey, V. (1963) Enzymes 2nd Ed. 7, 275-306

Massey, V. \& Veeger, C. (1961) Biochim. Biophys. Acta 48, 33-47

McNall, E. G. \& Atkinson, D. E. (1956) J. Bacteriol. 72, 226-229

Mejbaum-Katzenellenbogen, W. \& Drobryszycka, W. H. (1959) Clin. Chim. Acta 4, 515-522

Murphy, M. J., Siegel, L. M., Kamin, H. \& Rosenthal, D. (1973) J. Biol. Chem. 248, 2801-2814

Newman, B. M. \& Cole, J. A. (1977) J. Gen. Microbiol. 98, 369-377

Pateman, J. A., Rever, B. M. \& Cove, D. J. (1967) Biochem. J. 104, 103-111

Payne, W. J. (1973) Bacteriol. Rev. 37, 409-452

Perrie, W. T. \& Perry, S. V. (1970) Biochem. J. 119, 31-38

Prakash, O. M. \& Sadana, J. C. (1972) Arch. Biochem. Biophys. 148, 614-632

Radcliffe, B. C. \& Nicholas, D. J. D. (1968) Biochim. Biophys. Acta 153, 545-554

Siegel, L. M., Murphy, M. J. \& Kamin, H. (1973) J. Biol. Chem. 248, 251-264

Spencer, D., Takahashi, H. \& Nason, A. (1957)J. Bacteriol. 73, 553-562

Sumner, J. B. \& Gralen, N. (1938) J. Biol. Chem. 125, 33-36 
Vega, J. M., Guerrero, M. G., Leadbetter, E. \& Losada, M. (1973) Biochem. J. 133, 701-708

Venables, W. A., Wimpenny, J. W. T. \& Cole, J. A. (1968) Arch. Mikrobiol. 63, 101-121

Walker, G. C. \& Nicholas, D. J. D. (1961) Biochim. Biophys. Acta 49, 361-368
Ward, F. B. (1973) Ph.D Thesis, University of Birmingham Weber, K. \& Osborn, M. (1969) J. Biol. Chem. 244, 4406-4412

Zarowny, D. B. \& Sanwal, B. D. (1963) Can. J. Microbiol. 9, 531-539

Zumft, W. G. (1972) Biochim. Biophys. Acta 276, 363-375 